\section{Non-Formal Education Event Governance Strategies}

\author{
Małgorzata Pańkowska \\ Faculty of Informatics and Communication \\ University of Economics in Katowice, Poland \\ pank@ue.katowice.pl
}

\begin{abstract}
Purpose - The present paper aims to characterize the main differences and similarities among different strategies of event governance. Beyond that, there is a study analysis on non-formal education event governance.

Design/Methodology/Approach - The author's approach is based on the literature review and research works survey, concerning the governance strategies. The last part of the paper covers the Business Process Modeling Notation (BPMN) diagram and the Responsible-AccountableConsulted-Informed (RACI) model for visualization of the basic processes, decisions and stakeholders' roles in a non-formal education event.

Findings - Based on the analysis, it was found that the most appropriate strategy for the nonformal education event is the strategy, which strongly emphasizes the role of event facilitator. That role is confronted with the roles of other event stakeholders. In the paper, the characteristics of a project are confronted with the features of event.

Practical implications - The outcomes of the study can teach event managers how to share leadership and organize event activities.

Original value - The original value of the paper is that governance strategies are discussed as well as an event organizing approach is presented.
\end{abstract}

Article type - Research and literature general review.

Keywords - event governance, strategy, non-formal education, facilitators, Business Canvas Model, BPMN, RACI

\section{Introduction}

The paper concerns one of the lifelong learning forms, i.e. non-formal learning. In general, the lifelong learning approach focuses on fostering interchange of knowledge among educational institutions and on constant modernization of institutional solutions in the area of management and financing the higher education. That approach supports innovativeness of education, reinforces social cohesion of different university governance systems in different countries. Although the formal education is dominating, there are many initiatives of informal education, known also as Web 2.0 education. In this paper, formal, informal, and non-formal education forms are considered as complimentary to one another. The paper covers a general analysis of those three forms, because they all are provided and managed by university people. In this paper, the non-formal education is assumed to be realized by events. So the next part of the paper includes

\section{Non-Formal Education Event Governance Strategies}


IJSR

6 discussion on differences among projects and events, just to emphasize the particular value of events for non-formal education. Further, the strategies of event governance are discussed, and the most suitable strategy of non-formal education development is deeply characterized. Finally, the stakeholders' roles and processes for a non-formal education event governance are specified, presented in diagrams, and described.

\section{Formal, informal and non-formal education}

The distinction among the three forms of education is not only an administrative point of view. Formal education is linked with schools and training institutions, non-formal with community groups and other professional organizations, and the informal concerns an interaction with friends and colleagues at work. In general, adult learners are coming into the educational process with certain expectations and they have got particular goals connected with their professional, social and personal development. Learners have specific requirements regarding the learning process and when this process meets their needs, then their motivations for learning increase. They also have got a wide spectrum of prior knowledge and specific life experiences, so they prefer the educational organizations to be related with these experiences. For the analysis of informal and nonformal education for adults, the heutagogy development seems to be useful. According to Blaschke (2012), heutagogy is defined as self-determined learning rooted in andragogy. In that approach, learners are highly autonomous and self-organized. There is a focus on development of learner capacity and capability with the goal of teaching the people, who are well prepared to work in a complex-knowledge environment.

In formal learning processes, in European Union (EU) countries, schools and universities are obliged to respect the Bologna Process requirements concerning the university education. Therefore, each university ought to implement European Credit Transfer System (ECTS), European Qualification Framework (EQF) and National Qualifications Framework (NQF), which are instruments for the classification of qualifications according to a set of criteria for specified levels of learning (First Glossary..., 2010). According to the Bologna Process, in formal learning, students should develop their competences, i.e. get knowledge, develop skills and social positive attitudes. Informal learning is organized by students and for students. It does not have objectives in terms of formal learning outcomes. It concerns socialization, support, gathering opinions, consultancy, and self-directed learning. In contrast with the traditional view of teacher-centered learning via knowledge acquisition, informal learning is peerto-peer learning. So, learners read self-selected books and e-books, participate in selfstudy programs, watch YouTube films, navigate Internet support materials, seek advice from peers, participate in virtual communities of practice. Informal learning occurs in community, even if participants only observe, play, or take part in social events. In that learning process, the learner does not receive grades or certificates of completion. There are other important opportunities, i.e. opportunity to listen the lecture provided by a famous professor or expert.

Non-formal learning at university covers various less-structured learning events, such as night university visiting, open lectures, community sport events, conferences, seminars, summer schools, and company visits. Such forms of education do not either 
have curricula, accreditation or certification, but they are more structured than informal learning approaches. Non-formal learning is a method of communicating with people, of motivating them to participate, and of helping them to acquire necessary skills. In the non-formal education process, knowledge is developed by practice rather than by lecturing. It is strongly based on volunteer work and voluntary participation. It is costly, but the costs can be considered as promotion and marketing costs, funded by sponsors.

In this paper, non-formal education is considered as a system of events, which are realized for local community. The system of events covers seminars, workshops, performance, exhibitions, excursions, conferences, meetings, community assemblies, forums, demonstration classes, and sport competitions. The audience of the event is selected according to the event project goals. Some events are organized for children, other for older people or for teenagers. The events are organized by university staff and students, who are working as volunteers. If it is necessary, the events are financially supported by external institutions. Anyway, for each event the coordinator is selected and responsible for the event tasks realization, for the final success. Each event can be managed as a project, therefore, the canvas model can be specified for the non-formal education events (Figure 1).

\begin{tabular}{|c|c|c|c|c|}
\hline \multirow{3}{*}{$\begin{array}{l}\text { Key partnerships } \\
\text { Sponsors; } \\
\text { ICT solution providers; } \\
\text { Web service developers; } \\
\text { Event facilitators; } \\
\text { Academic \& } \\
\text { Administrative Staff; } \\
\text { Web portal } \\
\text { administration }\end{array}$} & \multirow{2}{*}{$\begin{array}{l}\text { Key activities } \\
\text { Event management; } \\
\text { Web portal } \\
\text { requirement } \\
\text { engineering; } \\
\text { Event realization, } \\
\text { control \& evaluation; } \\
\text { Event scheduling }\end{array}$} & \multirow{3}{*}{$\begin{array}{l}\text { Value } \\
\text { propositions } \\
\text { Values in public } \\
\text { services process; } \\
\text { Life style changes; } \\
\text { Long-life learning } \\
\text { habits; } \\
\text { Learner satisfaction; } \\
\text { Non-formal education } \\
\text { acceptance, efficiency } \\
\text { \& effectiveness }\end{array}$} & \multirow{3}{*}{$\begin{array}{l}\text { Customer } \\
\text { relationships } \\
\text { Analytics of educational } \\
\text { services; } \\
\text { Relations among learners } \\
\text { \& academic staff } \\
\text { Channels } \\
\text { Non-formal education } \\
\text { promotion portal; } \\
\text { Chat room, forums \& blogs; } \\
\text { Websites of mentors \& } \\
\text { associations; } \\
\text { Printing publicity \& } \\
\text { emailing }\end{array}$} & \multirow{3}{*}{$\begin{array}{l}\text { Customer } \\
\text { segments } \\
\text { Learners; } \\
\text { University } \\
\text { Academic Staff; } \\
\text { Students; } \\
\text { Learner } \\
\text { associations \& } \\
\text { assemblies; } \\
\text { Political parties; } \\
\text { Governmental } \\
\text { institutions }\end{array}$} \\
\hline & & & & \\
\hline & $\begin{array}{l}\text { urces } \\
\& \text { hardware; } \\
\text { support; } \\
\text { nal education } \\
\text { cumentation }\end{array}$ & & & \\
\hline \multicolumn{2}{|c|}{$\begin{array}{l}\text { Cost structure } \\
\text { Web portal development, implementation, } \\
\text { administration, \& maintenance; } \\
\text { Catering, transport \& hotel costs; } \\
\text { Event promotion costs }\end{array}$} & \multicolumn{3}{|c|}{$\begin{array}{l}\text { Revenue streams } \\
\text { Learning time reduction; Learning process simplification; Participant } \\
\text { satisfaction; Social relation development; Life status improvement; Lower } \\
\text { effort \& lower costs of formal education; University Social Responsibility } \\
\text { development; University-Business Alignment }\end{array}$} \\
\hline
\end{tabular}

Source: Own elaboration.

According to Bowdin et al. (2006), special events cover specific rituals, presentations, performances or celebrations which are planned and implemented to mark special occasions and to achieve particular cultural or corporate goals. In contrast to that exceptional events, the repeatable events are opportunities for a leisure, social or cultural experience outside the normal everyday duties. Events are characterized according to their size, cost and time for realization. The event size is measured by the

\section{Non-Formal Education Event Governance Strategies}

Figure 1. Business Canvas Model for NonFormal Education Development 
Pobrane z czasopisma International Journal of Synergy and Research http://ijsr.journals.umcs.pl

Data: 26/04/2023 13:02:10

68

IJSR

6

\begin{tabular}{|c|c|c|}
\hline $\begin{array}{l}\text { Criteria of } \\
\text { evaluation }\end{array}$ & Events & Projects \\
\hline Costs & $\begin{array}{l}\text { Event organization specific training, specially } \\
\text { arranged accommodation, rental of the space for the } \\
\text { event, travel costs as well as subsistence costs, i.e. } \\
\text { payment to hotels, meals, apartments renting for } \\
\text { presenters } \\
\text { Consumables: stationary, CDs, laser toner cartridges, } \\
\text { mass audience event safety and insurance }\end{array}$ & $\begin{array}{l}\text { Costs of technical, social or organizational } \\
\text { project solution conceptualization, analysis, } \\
\text { design, implementation, deployment, testing } \\
\text { and validation, control, monitoring, and post- } \\
\text { project evaluation and audit }\end{array}$ \\
\hline Quality control & Audience, mass applause, final services, volunteers & $\begin{array}{l}\text { Professional and beneficiary individual } \\
\text { evaluation, individually evaluated product }\end{array}$ \\
\hline Timing & $\begin{array}{l}\text { Preplanned and established schedule, which is } \\
\text { announced to participants, difficult to change; } \\
\text { modification would have an impact on the } \\
\text { organizers' image }\end{array}$ & Modified during the project realization \\
\hline Goals & $\begin{array}{l}\text { Preplanned, established, and announced to } \\
\text { participants, difficult to change, modification } \\
\text { would have an impact on the organizers' image, } \\
\text { modification is not well accepted by beneficiaries }\end{array}$ & $\begin{array}{l}\text { Modified during the project realization, in } \\
\text { agile method cases' application, project goals } \\
\text { modification is accepted }\end{array}$ \\
\hline Intensity of work & Exponential growth of work & Linear or exponential growth of work \\
\hline $\begin{array}{l}\text { Promotion and } \\
\text { advertising, publicity, } \\
\text { media liaison }\end{array}$ & $\begin{array}{l}\text { Necessary to collect event consortium at the start } \\
\text { and to collect the audience from the beginning, } \\
\text { long-term activity realized till the event days }\end{array}$ & $\begin{array}{l}\text { Intensive at beginning of the projects to create } \\
\text { the project consortium and after the end - to } \\
\text { distribute project products }\end{array}$ \\
\hline Venue & Offline and online & Offline and online \\
\hline Ticketing and entry & $\begin{array}{l}\text { Usually for commercial events or partly sponsored } \\
\text { event, no fees for fully sponsored events }\end{array}$ & Not applicable \\
\hline Staging & Planning, realization, control, monitoring, evaluation & $\begin{array}{l}\text { Conceptualization, analysis, design, } \\
\text { implementation, deployment, control, } \\
\text { monitoring, evaluation, audit }\end{array}$ \\
\hline Crowd control & Mandatory for mass events & Not applicable \\
\hline Safety and security & Mass audience safety & Security of products and participants \\
\hline Communication & Among event committee members & Among project consortium members \\
\hline $\begin{array}{l}\text { Transport, parking, } \\
\text { toilets, catering, } \\
\text { first aid }\end{array}$ & $\begin{array}{l}\text { For audience and for event committee members, } \\
\text { performers }\end{array}$ & For project consortium members \\
\hline Sponsors & Sponsored or volunteer work & Sponsored or volunteer work \\
\hline $\begin{array}{l}\text { Benefits and } \\
\text { beneficiary } \\
\text { relationship }\end{array}$ & Occasional transactions, focus on short-term effects & $\begin{array}{l}\text { Long-term impacts, projects results' durability } \\
\text { evaluation }\end{array}$ \\
\hline $\begin{array}{l}\text { Management } \\
\text { methods }\end{array}$ & $\begin{array}{l}\text { Own, PMBOK, no prototypes but trial and demo } \\
\text { versions }\end{array}$ & $\begin{array}{l}\text { Prince2, PMBOK, agile methods, prototyping, } \\
\text { trial and demo versions }\end{array}$ \\
\hline
\end{tabular}

Table 1.

Events vs. Projects

- similaries and

discrepancies

Source: Own elaboration. 
number of participants, organization team members, or events partners. Major events are able to attract significant visitor numbers, media coverage and economic benefits. Table 1 includes a comparison of events and projects, just to emphasize that they are different forms of activity. The events are more short-term effects-oriented than projects. There are many techniques, which can be successfully applied for the event as well as for project management, e.g. Gantt chart, Earned Value, brainstorming, Fishbone/Ishikawa Diagrams, or Strengths, Weaknesses, Opportunities, Threats Development (SWOT) analysis. The quality of the organization committee is important for events as well as for projects. Usually, there is a need to find an appropriate person, who would be the leader of all the activities, and who would be able to create a positive image of the group work to an external audience.

\section{Event governance fundamental activities}

According to Gattiker (2013), governance is about how companies should be run. Without having the appropriate governance policies and procedures in place, the company cannot achieve compliance with relevant regulations and laws. Governance describes the mechanism a business organization uses to ensure that it constituents follow its established processes and policies. Governance can be considered as a process during which senior management exerts strategic control over business functions through policies, objectives, delegation of authority and measurement. Governance is managerial control over all other business processes to ensure that processes are realized effectively to meet the organization's business needs.

Good governance is oriented towards:

- Transparency increase and dissemination of the governance rules and procedures.

- Administrative work reducing and eliminating the intermediaries, through putting procedures online.

- Service delivery improvement, reducing time for completing transactions.

- End beneficiary service performance improvement, increasing the ability of managers to monitor tasks of user servants, increase of the speed and efficiency of workflow and data exchange.

- Empowerment of end beneficiary.

- Providing better control of IT investments and expenditures (Almunawar et al., 2012; Lee Lock, 2009).

As governance includes the business strategy development and implementation, a certain definition of strategy must be approved. In general, strategy is defined as the determination of a course of action to be followed to achieve a desired goal or position (Lee, Clark, 1999). According to Mintzberg and Quinn, strategies have two main characteristics (Mintzberg, Quinn, 1991). They are made in advance of the actions to which they are applied and they are developed consciously and purposefully. They concern the future, but from the present point of view. So, it makes them unverifiable a priori. Therefore, it would be better to assume the strategy goal specification in 3 horizon periods of time, i.e. 12 months, 12-36 months, and more than 36 months, i.e. $36+$ months. The first period of time seems to be rather clear for business organization, so then more promises can be given. Strategy can also be discussed as a manoeuvre intended to outwit an

\author{
Non-Formal \\ Education Event \\ Governance \\ Strategies
}


IJSR

6

opponent or competitor (Mintzberg, Quinn, 1991). A well developed strategy helps to allocate an organization's resources into unique and viable way based on the business unit's relative internal competencies and shortcomings. Business strategy development includes strategy goals formulation, external and internal analysis of the business organization, and finally, formulation and assessment of the strategy. Business strategy should focus on specification of values, purposes and premises made by the governance team to the final result beneficiaries.

According to Mintzberg and Quinn, business strategy is the pattern of decisions in a company that determines and reveals its objectives, produces the principal policies and plans for achieving the goals (Mintzberg, Quinn, 1991). Business strategy always concerns the change, although it is really about continuity and it is combined with imposing stable pattern of behaviors on an organization. The maintaining of the current status means a change, because of the external environment change impact. The strategy management is identified with the change management. The strategy managers have to recognize when a shift of a strategic nature is possible, desirable, necessary, and then to act. Strategic purposes are as follows: emphasize customer orientation, better customer purchase support, customer retention increase, increase of productivity, and the development of new products (Marchand, 2000).

The event governance strategy is derived from the strategic vision of the whole business organization, e.g. university. In this paper, the strategy of event governance is understood as a general way to cope with all problems of event. Strategy is defined as a fundamental principle of all business organization activities. These activities are determined by basic factors, which can be a rule, a person, a concept, or even a certain group of people. Taking into account that the event is comparable to project, at first, the strategies proposed by Cadle and Yeates (2008) are discussed in the aspect of their usefulness for the event governance. Cadle and Yeates analyse different organizational strategy models based on the work of Charles Handy, who classified organizations according to the degree of centralization and the degree of formality in the way the business activities are realized (Cadle, Yeates, 2008). So, Cadles and Yeates specify the following strategies:

- Power-based strategy: focus on centralization, demonstrating sponsorship, informal strong authority, charismatic leaders, critical resource owner. For each final product, the authority approval is necessary.

- Bureaucracy-based strategy: focus on centralization, playing by the rules, formal control of decisions, particularly those concerning the expenditure and cost budgeting.

- Task-based strategy: distribution of the tasks to the lowest organizational hierarchy level, formal framework for reporting and decision making.

- Individualism-oriented strategy: focus on individual opinions, problem-forcing teams, unique performance, working on consensus.

Kendall and Kendall (1993) analyse strategy metaphors that help understand contradictions, contexts, paradoxes of strategies. The organizational metaphors discussed by them are useful for understanding the complexity of organizations, their organizational cultures, management styles, ideology, key values and key performance indicators. They deliberate the following metaphors: 
- Game, which requires the identification of the goals, risks, teamwork, leadership. The team success depends on the competencies of each member at each position working with all other members toward a common goal.

- Machine, where the goals are predefined and the organization's performance is calculated. The team members are interchangeable like machine elements.

Non-Formal Education Event Governance Strategies

- Journey, according to which the organization future is unpredictable and risky. However, the opportunities and benefits are not excluded. The leader focuses strongly on cooperation and motivation assurance just to complete the sequence of activities and to achieve the assumed goals.

- Jungle, which as a strategy is similar to anarchy, where everybody is working for himself. The usage of any means to achieve the goals is permitted. Negotiations with the organization external environment to receive some benefits are required.

- Family, which covers people sharing the business organization's resources, each member has a role to play, as well as she/he is protected by other family members.

- Zoo is a metaphor to reflect a chaotic and unpredictable existence. People do not cooperate, but they focus on the personal goal achievement. However, they are subordinated an external director, who is able to oversee their behaviors.

- Society focuses on the political interactions of its members, who are engaged in negotiations to achieve their own individual goals.

- War concerns unpredictable and risky situations, internal conflicts, and mechanisms of looking for enemies. The business leaders are oriented towards negotiations and motivation for goal achievement.

The presented metaphors are accepted to explain the business organization governance strategy. Each metaphor emphasizes different features that distinguish forms of governance from each other. Going further, Germonprez et al. (2014) assume that governance forms, i.e. autocracy, stratocracy, and enlightened absolutism are associated with the metaphors such as machine, war and journey. Oleński (2006) does not use metaphors, but he explains the different forms of information governance, which can be useful also to analyse the event governance. The forms discussed by Oleński (2006) are as follows:

- Bureaucracy, which is based on rules, regulations, policies and protocols. Organizational hierarchies are developed to ensure that organizational members adhere to the rules. So, creative individuals perceive that strategy as very uncomfortable for their goals' achievement.

- Meritocracy, where the leaders have rights and responsibilities because of their intellect and their accomplishments.

- Democracy as a form in which governing power is derived from the people, either by direct referendum or by means of elected representatives.

- Politocracy, in which the political elites control the society and the economy.

Taking into account the above forms, meritocracy, as a governance strategy, is suitable for non-formal education, which is based on knowledgeable authorities, i.e. lecturers, workshop presenters and seminar's leaders. Even a competition among them is a key factor for the non-formal education successes. Adhocracy, mentioned by Germonprez et al. (2014), can also be considered as a flexible strategy of event governance. Adhocracy means that people create a team just in case, spontaneously, occasionally, because they 
IJSR

6 have noticed an opportunity to receive any benefits, i.e. personal satisfaction, financial compensations of their works, respect, and approval ensured by other people. Adhocracy is similar to game in the aspect of people engagement. People may contribute and the success depends on how the community functions as a result of people's cooperation. Moreno-Jiménez et al. (2006) argue that e-cognocracy is a cognitive democracy oriented to the exploration and sharing of knowledge. It is identified with the incorporation of the knowledge and the preferences of individuals involved in the decision-making processes. The key idea of e-cognocracy is to educate people, promote relations among them and improve the quality of life and cohesion, and construct the future in a world of complexity increase. Therefore, that strategy is also useful for non-formal education event governance.

\section{Facilitation-oriented strategy of non-formal education event governance}

Non-formal education is usually concerned with an immediate and practical mission. Practical orientation of non-formal education governance requires focusing on democratic discussions and dialogues, critical analysis of factors in the socio-technobiological environment, self-analysis and reflection, autonomous cognition, acquiring new knowledge and new communication abilities like reading and writing, training for practical skills, and relating education to life, society and work experiences. According to Cabag (1999), the fundamental principles of non-formal education are as follows:

- Utilization of native norms, traditions, cultures to fulfill the learning community request and solve problems.

- Active participation of the learning community, as well as governmental institutions, agencies and other civic organization in non-formal education events.

- Use of the learning community capabilities and resources in the development and enrichment of the learning process.

The non-formal education activities' realization strongly depends on the availability of the local facilitators. According to Hogan (2002), a facilitator is a person who has the role of helping participants to learn. Adults should not be trained, but they ought to be facilitated. The facilitation comes up with more creative process. It enables people to hear others and perhaps shift from polarized paradigms. Facilitators are to support the understanding yourself and others. They simplify the mutual communication. They should encourage to critical thinking and to innovativeness development. Facilitators in the communication process are not oriented towards argumentation, but rather towards creation of mutual understanding. They show the learners some patterns of behaviors. That role is similar to the role of leader, who is expected to start the educational process, to build and rebuild the organization team, to set high level standards and to hold everyone to them. She/he always keeps control, motivates people and never stops adapting. The learning facilitation strategy is original in comparison with formal and informal learning and it is similar to the strategies emphasizing the role of leader. However, the non-formal education events require identification of the whole group of stakeholders, who are involved in the process and decision making.

The non-formal education (NFE) stakeholders realize activities, which can be integrated and consolidated in the RACI model. The "RACI" acronym is developed as follows: 
Pobrane z czasopisma International Journal of Synergy and Research http://ijsr.journals.umcs.pl Data: 26/04/2023 13:02:10

- Responsible (R): refers to the person, who must ensure that activities are completed successfully.

- Accountable (A): refers to the person or group, who has the authority to approve or accept the execution of learning activity.

- Consulted (C): refers to the people, whose opinion are sought on an activity.

- Informed (I): refers to the people, who are kept up to date on the progress of an activity (Elia, Poce, 2010).

\begin{tabular}{|c|c|c|c|c|c|c|c|c|}
\hline $\begin{array}{c}\text { Key } \\
\text { Management } \\
\text { Practices }\end{array}$ & $\begin{array}{l}\text { University } \\
\text { President }\end{array}$ & $\begin{array}{c}\text { NFE } \\
\text { Programme } \\
\text { Coordinator }\end{array}$ & $\begin{array}{l}\text { NFE Event } \\
\text { Coordinator }\end{array}$ & $\begin{array}{l}\text { NFE Event } \\
\text { Facilitator }\end{array}$ & $\begin{array}{c}\text { NFE } \\
\text { Event IT } \\
\text { Staff }\end{array}$ & $\begin{array}{c}\text { NFE Event } \\
\text { Promotion } \\
\text { Staff }\end{array}$ & $\begin{array}{l}\text { NFE Event } \\
\text { Presenter }\end{array}$ & $\begin{array}{c}\text { NFE } \\
\text { Event } \\
\text { Learner }\end{array}$ \\
\hline $\begin{array}{l}\text { NFE Event } \\
\text { Conceptualization, } \\
\text { Vision, Mission, } \\
\text { Objectives } \\
\text { Specification }\end{array}$ & $A$ & $C$ & C & $R$ & $C$ & I & $C$ & I \\
\hline $\begin{array}{l}\text { NFE Event } \\
\text { Operational } \\
\text { Planning }\end{array}$ & $C$ & $A$ & R & C & $C$ & $C$ & $C$ & I \\
\hline $\begin{array}{l}\text { NFE Event } \\
\text { Material \& } \\
\text { Financial } \\
\text { Resources } \\
\text { Acquisition }\end{array}$ & $A$ & $\mathrm{R}$ & $\mathrm{R}$ & $C$ & I & I & $C$ & $C$ \\
\hline $\begin{array}{l}\text { NFE Event } \\
\text { Presenter Inviting }\end{array}$ & $C$ & $C$ & $C$ & $\mathrm{R}$ & I & $C$ & $A$ & $C$ \\
\hline $\begin{array}{l}\text { NFE Event } \\
\text { Controlling }\end{array}$ & $C$ & $C$ & $\mathrm{R}$ & $C$ & $C$ & I & I & I \\
\hline $\begin{array}{l}\text { NFE Event } \\
\text { Promotion } \\
\text { \& Audience } \\
\text { Management }\end{array}$ & I & 1 & $C$ & $C$ & I & $\mathrm{R}$ & I & $A$ \\
\hline $\begin{array}{l}\text { NFE Event } \\
\text { IT Support }\end{array}$ & I & I & $C$ & I & $\mathrm{R}$ & $C$ & $C$ & I \\
\hline
\end{tabular}

Non-Formal Education Event Governance Strategies

Table 2.

RACI Chart for NonFormal Education Event Stakeholders

Source: Own elaboration.

Non-formal education event stakeholder structure (proposed in Table 2) covers the most important people, i.e. University President (UP), Non-Formal Education Programme Coordinator (NFEPC), Non-Formal Education Event Coordinator (NFEEC), Non-Formal Education Event Facilitator (NFEEF), Non-Formal Education Event Information Technology Staff (NFEEITS), Non-Formal Education Event Promotion Staff (NFEEPS), Non Formal Education Event Presenter (NFEEP), and Non Formal Education Event Learner (NFEEL). In this paper, the NFEPC stakeholder is responsible for all non-formal education events and activities realized at the university. The NFEEC stakeholder is like a project manager and she/he is responsible 
IJSR

6

Fiĝure 2.

Non-Formal Education Governance Process just for one particular event, for the operational planning, resource acquisition and controlling. The NFEEF stakeholder is the particular event leader, responsible for the event objectives specification, the event conceptualization and appropriate presenters' invitation. The other roles are specified in Table 2. The proposed stakeholders' roles are further included in the BPMN process diagram for the non-formal education event governance. The proposed roles are combined with activities to simplify the controlling of the event.

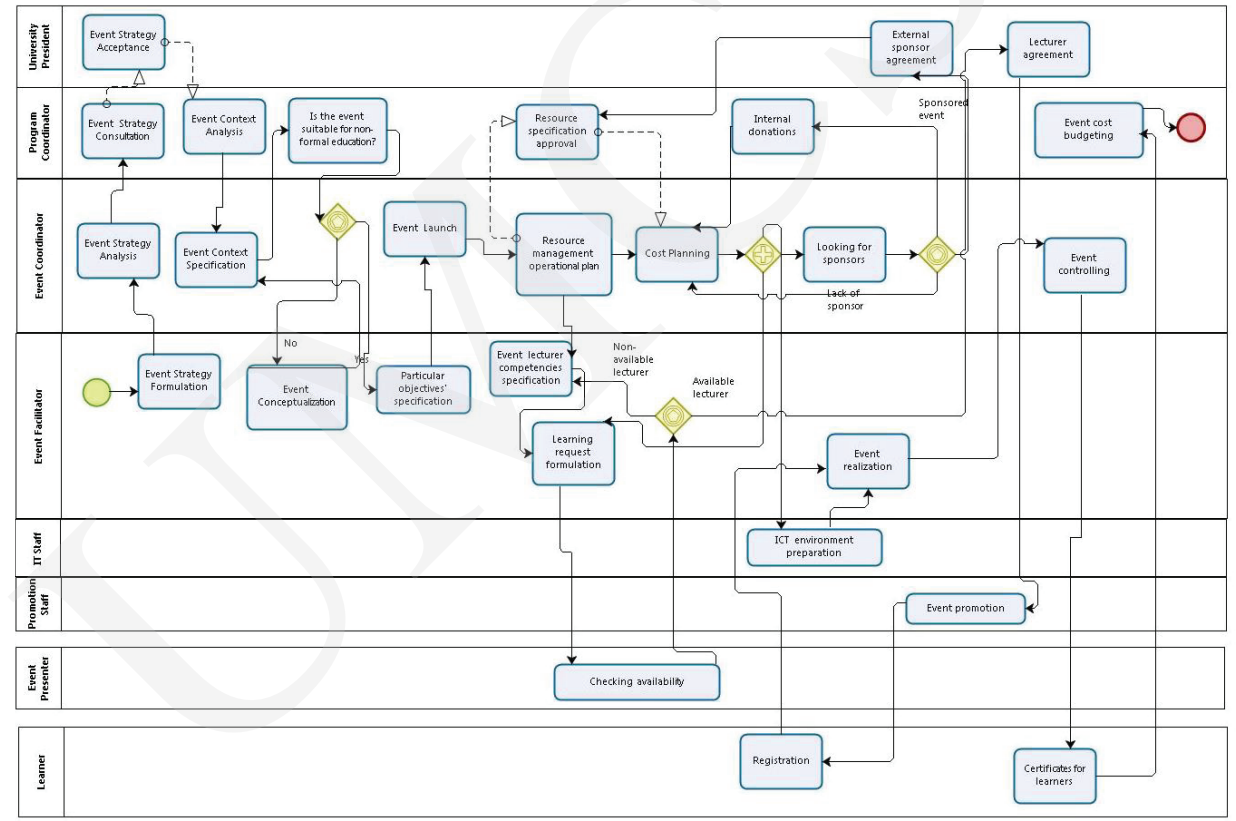

Source: Own elaboration.

\section{Conclusions}

The non-formal education has been lately developed at universities, because of its huge impact on the university image, on program of studies and even on research. However, the decision to develop or not to develop non-formal education should be idiosyncratic for each university. Formal education is mandatory, informal is preferred by students, but non-formal education decision requires an evaluation if it is really cost-effective event, taking into account the tangible and intangible expenditures. For universities, the non-formal education is an opportunity to develop strong relations with business organizations. Although it is based on volunteers' works, it requires a strong promotion and marketing plans.

The development of non-formal education requires new methods and approaches. In this paper, the event governance approach was presented. The literature studies permit the conclusion that strategies of governance are different and some of them are 
useful for event governance. The proposed event governance strategy emphasizes the role of facilitator and as such is facilitation-oriented. The facilitator's activities were confronted with the tasks of other stakeholders.

\section{References}

Almunawar, M.N., Cheng Low, P.K., Rahman, M.H., Mohiddin, F. (2012). From E-Government to E-Governance. Winning People's Trust, [in:] A. Manoharan, M. Holzer (Eds.), E-Governance and Civic Engagement. Factors and Determinants of E-Democracy, IGI Global, Hershey, pp. 613-637.

Blaschke, L.M. (2012). Heutagogy and Lifelong Learning: A Review of Heutagogical Practice and Self-Determined Learning, The International Review of Research in Open and Distance Learning, Oldenburg University and University of Maryland University College, vol. 13, no. 1, pp. 56-71.

Bowdin, G., Allen, J., O'Toole, W., Harris, R., McDonnell, I. (2006). Events Management, Elsevier, Amsterdam.

Cabag, R.C. (1999). Nonformal Education. A Handbook for Teacher Education Students, NFE Administrators, and Extension Program Implementors, Katha Publishing Co., Quezon City.

Cadle, J., Yeates, D. (2008). Project Management for Information Systems, Prentice Hall, Harlow.

Elia, G., Poce, A. (2010). Future Trends for "i-Learning” Experiences. In: G. Elia, A. Poce (eds.), Open Networked "i-Learning", Models and Cases of "Next-Gen" Learning, Springer, New York, pp. 133-176.

First Glossary, Knowledge Skills And Attitudes (KSA) Effects (2010). Retrieved September 20, 2016 from: http://www.firstebtn.eu/files/FIRST_Glossary.pdf

Gattiker, U.E. (2013). Social Media Audit: Measure for Impact, Springer, Heidelberg.

Germonprez, M., Kendall, J.E., Kendall, K.E., Young, B. (2014). Collectivism, Creativity, Competition, and Control in Open Source Software Development: Reflections on the Emergent Governance of the SPDX Working Group. International Journal of Information Systems and Management, vol. 1, no. 1/2, pp. 125-145.

Hogan, Ch. (2002). Understanding Facilitation, Theory and Principles, Kogan Page, London.

Kendall, J.E., Kendall, K.E. (1993). Metaphors and Methodologies: Living Beyond the Systems Machine. MIS Quarterly, vol. 17, no. 2, pp. 149-170.

Lee, H.G., Clark, T.H. (1999). Strategies in Response to the Potential of Electronic Commerce. Market Process Reengineering Through Electronic Market Systems: Opportunities and Challenges. In: R.D. Galliers, D.E. Leidner, B.S.H. Baker (eds.), Strategic Information Management. Challenges and Strategies in Managing Information Systems, ButterworthHeinemann, Oxford.

Lee Lock, L. (ed.), (2009). IT Governance in a Networked World. Multi-Sourcing Strategies and Social Capital for Corporate Computing, Information Science Reference, Hershey, pp. $13-34$.

Marchand, D.A. (2000). Competing with Information, Wiley \& Sons, Chichester.

Moreno-Jiménez, J.M., Piles, J.J., Ruiz Más, J., Salazar, J.L. (2006). E-Cognising: The E-Voting Tool for E-Cognocracy. Retrieved May 20, 2017 from: http://www.rij.eng.uerj.br/ scientific/2008/sp082-03.pdf

Mintzberg, H., Quinn, J.B. (1991). The Strategy Process, Concepts, Contexts, Cases, Prentice Hall, Englewood Cliffs.

Oleński, J. (2006). Infrastruktura informacyjna państwa w globalnej gospodarce, Uniwersytet Warszawski, Warszawa.

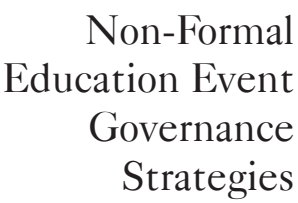

Non-Formal Governance Strategies 
